\title{
First Assessment of Carbon Stock in the Belowground Biomass of Brazilian Mangroves
}

\author{
DANIEL M.C. SANTOS ${ }^{1,2}$, GUSTAVO C.D. ESTRADA ${ }^{1}$, VIVIANE FERNANDEZ ${ }^{3}$, \\ MARCIEL R.M. ESTEVAM' ${ }^{1}$ BRUNNA T. DE SOUZA ${ }^{1}$ and MÁRIO L.G. SOARES ${ }^{1}$ \\ ${ }^{1}$ Universidade do Estado do Rio de Janeiro, Faculdade de Oceanografia, Departamento \\ de Oceanografia Biológica, Núcleo de Estudos em Manguezais, \\ Rua São Francisco Xavier, 524, 4023-E, Maracanã, 20550-013 Rio de Janeiro, RJ, Brazil \\ ${ }^{2}$ Faculdades São José, Escola de Saúde, Av. de Santa Cruz, 580, Realengo, 21710-232 Rio de Janeiro, RJ, Brazil \\ ${ }^{3}$ Universidade Federal Fluminense/UFF, Centro de Estudos Gerais, Instituto \\ de Geociências, Departamento de Análise Geoambiental, \\ Av. Gal. Milton Tavares de Souza, s/n, Campus da Praia Vermelha, Boa Viagem, 24210-340 Niterói, RJ, Brazil
}

Manuscript received on July 27, 2016; accepted for publication on February 17, 2017

\begin{abstract}
Studies on belowground roots biomass have increasingly reported the importance of the contribution of this compartment in carbon stock maintenance in mangrove forests. To date, there are no estimates of this contribution in Brazilian mangrove forests, although the country has the second largest area of mangroves worldwide. For this study, trenches dug in fringing forests in Guaratiba State Biological Reserve (Rio de Janeiro, Brazil) were used to evaluate the contribution of the different classes of roots and the vertical stratification of carbon stock. The total carbon stock average in belowground roots biomass in these forests was $104.41 \pm 20.73$ tC.ha ${ }^{-1}$. From that, an average of $84.13 \pm 21.34$ tC.ha ${ }^{-1}$ corresponded to the carbon stock only in fine roots, which have diameters smaller than $5 \mathrm{~mm}$ and are responsible for over $80 \%$ of the total belowground biomass. Most of the belowground carbon stock is concentrated in the first $40 \mathrm{~cm}$ below the surface (about $70 \%$ ). The root:shoot ratio in this study is 1.14 . These estimates demonstrate that the belowground roots biomass significantly contributes, more than $50 \%$, to the carbon stock in mangrove forests. And the mangrove root biomass can be greater than that of other Brazilian ecosystems.
\end{abstract}

Key words: global climate change, Guaratiba State Biological Reserve, roots, Sepetiba bay, trench method.

\section{INTRODUCTION}

In recent decades, the scientific community has issued several advances and alerts with regard to global climate change, its implications, and its origins (IPCC 2014). These changes have their origin associated with the increasing emissions of

Correspondence to: Mário Luiz Gomes Soares

E-mail: mariolgs@uerj.br greenhouse gases (GHG) such as carbon dioxide, sulfur, and nitrogen oxides (IPCC 2014). According to the monitoring carried out by the US Oceanic and Atmospheric Administration Agency, atmospheric carbon concentration reached the 400 ppm mark in 2013 (NOAA 2013).

Forests play an important role in the carbon cycle and its regulation and potentially play important parts in carbon sequestration and stock 
because of their large vegetal biomass as a major reason (Brown et al. 1992, Vieira et al. 2008, Guo et al. 2010, Donato et al. 2011). It is estimated that tropical forest ecosystems worldwide can store up to $193 \mathrm{PgC}$ (Saatchi et al. 2011). Conversely, the loss of forest systems would imply the loss of the capacity to mitigate or reduce GHG concentration through organic carbon sequestration and stock (Harris et al. 2012, Zarin 2012), and it will contribute to additional emissions of carbon that is stored in these systems. Therefore, various forms of mitigation have been studied to reduce GHG concentration and/or emissions (IPCC 2014). Among them are those that use the conservation of vegetal biomass of forest ecosystems as carbon sinks and sequestrants (Cenamo et al. 2010, SotoPinto et al. 2010).

Mangrove forests have a tropical and subtropical distribution (Tomilson 1986, Schaeffer-Novelli et al. 2000) and great potential as atmospheric carbon sinks and sequestrants (Siikamaki et al. 2012). Even though they occupy less than $1 \%$ of the global tropical forest cover (Giri et al. 2011), these forests can globally store $4.03 \mathrm{PgC}$ (Twilley et al. 1992), 13.1 PgC (Alongi 2014) to $20 \mathrm{PgC}$ (Donato et al. 2011) of organic carbon. Both carbon stock and emission estimates based on the protection or loss of this system still have great uncertainty. This is because of the absence of information, both in relation to sequestration rates and carbon stocks in these forests on global and local scale (Donato et al. 2011). In addition, mangrove forests play an important role in the biogeochemical carbon cycle as presented by Alongi and Mukhopadhyay (2015), Bouillon et al. (2008, 2003) and Twilley et al. (1992), mainly due to its location in direct contact with the tides of the oceans, which provides an exchange of organic matter, with this adjacent environment, different from other forest systems.

According to Donato et al. (2011), carbon is mostly stored in the sediments, aerial vegetal biomass, and belowground biomass in the descending order. However recent studies suggest the importance of the carbon stock in the belowground biomass of mangrove forests (Abohassan et al. 2012), there are few estimates regarding this compartment (Komiyama et al. 2008). Among the estimates available in literature, a few are based on the use of trenches sampling, which despite being extremely labor intensive provide more accurate estimates for collecting larger volumes of roots than those provided by sampling based on core.

In Brazil, mangroves occur almost along the entire length of the Brazilian coast (SchaefferNovelli et al. 1990), stretching over $6,786 \mathrm{~km}$ (Schaeffer-Novelli et al. 2000). According to recent estimates, Brazil ranks second in the total area occupied by mangroves, with 1,071,083.74 ha (Magris and Barreto 2010), and has the largest contiguous mangrove area in the world, with 742,400 ha (Nascimento Jr et al. 2013). Therefore, the understanding of the contribution of Brazilian mangroves for carbon stock is fundamental to further understand the role of these forests on a global scale. Nevertheless, there is no estimate for the carbon stock in belowground biomass of these forests along the Brazilian coast.

Therefore, this study aims to present the first estimate of carbon stock in belowground biomass of Brazilian mangrove forests, using mangroves located in southeastern Brazil as a case study. In addition to the quantification of the total belowground biomass, this study was also based on the following question: what is the contribution of the belowground biomass to carbon stock in mangrove fringes in the Sepetiba bay?

\section{MATERIALS AND METHODS}

\section{STUDY AREA}

The study area is located in the Sepetiba Bay (Figure 1), approximately $70 \mathrm{~km}$ away from the center of Rio de Janeiro city, southeastern Brazil. 
Guaratiba mangrove is protected under the Guaratiba State Biological Reserve. According to the Köppen classification, the climate can be divided into Aw, tropical hot and humid climate with a dry season in winter, typical of the lowland, and Af, tropical hot and humid climate without a dry season, characteristic of the adjacent slopes. The average annual temperature is $23.5^{\circ} \mathrm{C}$, and the average annual rainfall is $1067 \mathrm{~mm}$, with January and March being the months with the highest rainfalls and June and August the driest ones. The tidal regime is microtidal, with amplitude smaller than two meters. In the mangroves of Guaratiba, the innermost parts of the intertidal zones are only reached by spring tides, which create hypersaline plains. Therefore, there is a structural development gradient of the forest due to the reduction of tidal flood frequency and increased salinity toward the interior, characterizing three distinct physiographic types: fringe, basin, and transition with hypersaline plains. The sampling sites are located between coordinates $23^{\circ} 00^{\prime}$ ' $54^{\prime \prime} \mathrm{S}$; $43^{\circ} 34^{\prime} 44^{\prime \prime} \mathrm{W}$ and $23^{\circ} 00^{\prime}$ 40"'S; 430 34' 14'”.

Three mangrove species described for this part of the Brazilian coast occur in the study area: Avicennia schaueriana, Laguncularia racemosa, and Rhizophora mangle. The fringe forests have a living basal area contribution of $65.2 \%$ of $A$ schaueriana, $1.4 \%$ of L. racemosa, and $24 \%$ of $R$. mangle (Estrada et al. 2013). The basin forests have a living basal area contribution of $55 \%$ of $A$. schaueriana, $0.2 \%$ L. racemosa, and $31.4 \%$ of $R$. mangle. The transition forests to hypersaline plains have a living basal area contribution of $32.7 \%$ of $A$. schaueriana and $46.5 \%$ of $R$. mangle. The maximum diameter is $40 \mathrm{~cm}$ in fringe forest, where this study was developed. The forest structure parameters, as density, mean $\mathrm{DBH}$, mean height and salinity are presented in table I.

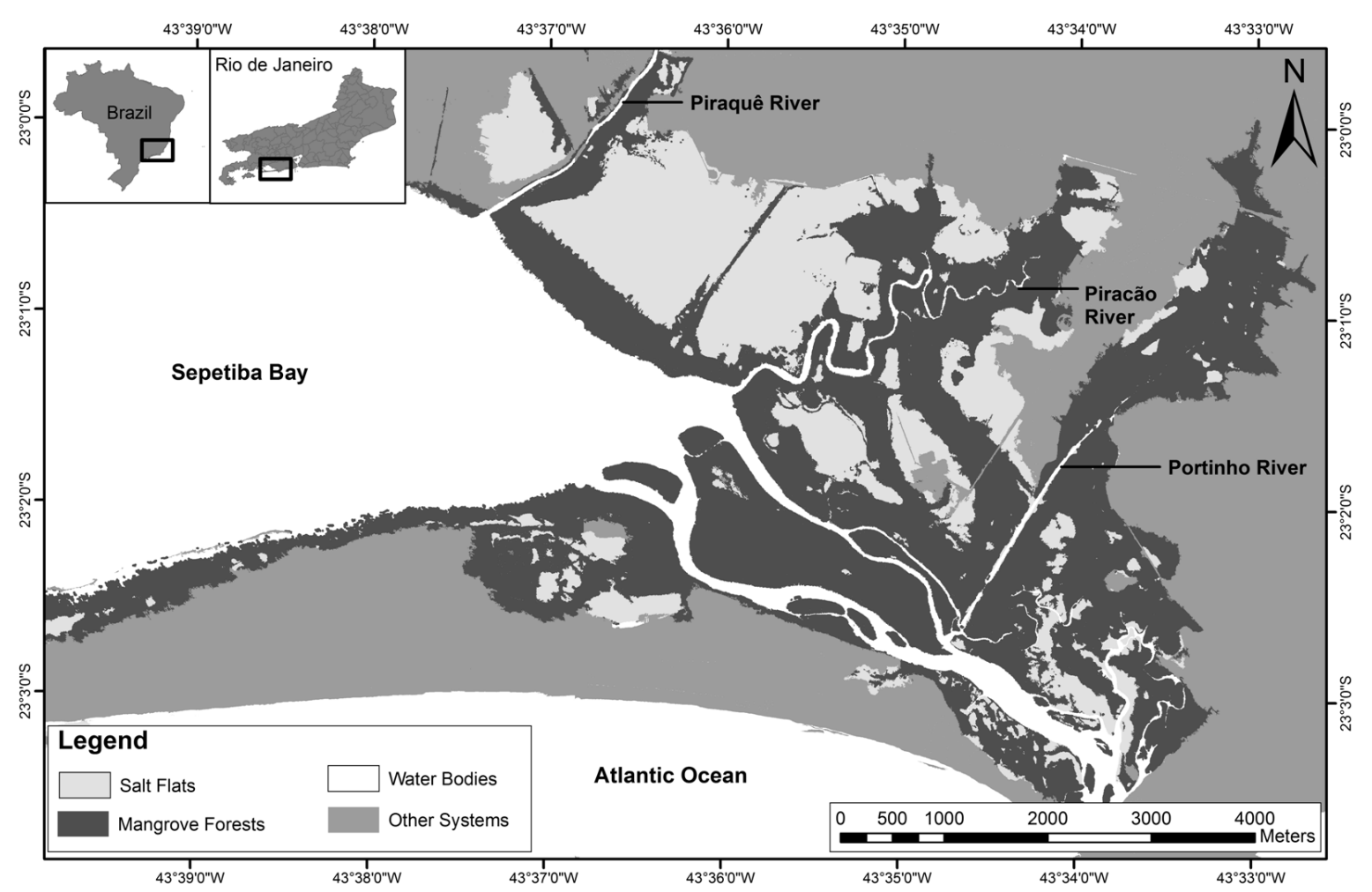

Figure 1 - Mangrove sampling sites on study area location, along the Piracão river in Guaratiba, Rio de Janeiro, RJ. 
TABLE I

Structures parameters and intertiscial salinity from diferents physiographic type of Guaratiba mangrove. (mean \pm standart deviation). Data from Estrada et al. (2013).

\begin{tabular}{ccccc}
\hline $\begin{array}{c}\text { Physiographic } \\
\text { type }\end{array}$ & $\begin{array}{c}\text { Density } \\
\text { (trunks. } \\
\text { ha }^{-1} \text { ) }\end{array}$ & $\begin{array}{c}\text { Mean } \\
\text { DBH } \\
(\mathbf{c m})\end{array}$ & $\begin{array}{c}\text { Mean } \\
\text { Height } \\
(\mathbf{m})\end{array}$ & Salinity \\
\hline \multirow{2}{*}{ Fringe } & $5895 \pm$ & $10.1 \pm$ & $7.4 \pm$ & $35.3 \pm$ \\
& 9399 & 3.8 & 2.3 & 7.3 \\
Basin & $10260 \pm$ & $5.8 \pm$ & $5.0 \pm$ & $40.9 \pm$ \\
& 8554 & 2.0 & 1.8 & 7.5 \\
Transition & $19001 \pm$ & $3.0 \pm$ & $2.0 \pm$ & $42.2 \pm$ \\
& 14426 & 1.6 & 1.2 & 10.1 \\
\hline
\end{tabular}

METHODS

The belowground root biomass was estimated using trenches digging. This sampling method was adopted because it allows more robust estimates as it evaluates a higher volume of sampled sediment in its entirety and reduces the loss of material (Komiyama et al. 1987). Five trenches with 1 $\mathrm{m}^{3}$ volume $(1 \times 1 \times 1 \mathrm{~m})$ were excavated (Figure $2)$. The trenches were all positioned in the fringe forest on the margin of the Piracão river, located in the Guaratiba State Biological Reserve, and were placed approximately 150-200 m from each other, covering approximately $1 \mathrm{~km}$ of the forest. The excavation was stratified into 10 strata of $10 \mathrm{~cm}$ each. The substrate removed from each stratum was washed still in the study area, using a $1 \mathrm{~mm}$ mesh sieve. Roots were manually separated and cleaned from sediment excess and other organic debris. The material screened in the field was taken to the laboratory for a new wash in running water and full removal of the sediment using $0.25 \mathrm{~mm}$ mesh sieves. Roots were separated into the following diameter classes: less than $5 \mathrm{~mm}$; between 5 and $10 \mathrm{~mm}$; between 10 and $20 \mathrm{~mm}$; between 20 and $50 \mathrm{~mm}$ and larger than $50 \mathrm{~mm}$. This roots was not separated in live and dead roots. Apart from these, pneumatophores were also collected and stocks related to these structures were recorded in the first stratum. The screened roots were stored and oven dried at $70^{\circ} \mathrm{C}$ to obtain the dry weight.

To transform biomass into carbon, the specific carbon contents found by Rodrigues et al. (2014) were applied: $42.6 \%$ for $L$. racemosa and $A$. schaueriana and $40 \%$ for $R$. mangle. Because the three species occur in Guaratiba's fringe forests, it was necessary to apply the weighting method of the carbon content, considering the relative dominance of each species in terms of basal area as described by Rodrigues et al. (2014). To compare the results of this study to the literature that present only belowground or aboveground biomass, biomass was converted into carbon stock. For aboveground biomass the carbon content of $45 \%$ provided by Twilley et al. (1992) was applied, and for belowground biomass the carbon content of $40.8 \%$ proposed by Khan et al. (2007) was used.

To improve reliability of these estimates, structural characterization was performed in the vicinity of each trench. For each sampling point, a $100 \mathrm{~m}^{2}$ area plot was defined, with the trench at its center. All plants with more than $1 \mathrm{~m}$ tall were identified at the species level, tree heights were recorded with an optical rangefinder and the diameter measured at breast height (DBH; $1.30 \mathrm{~m}$ above ground level) of all trunks was measured. The trunks also had their status (dead or alive) verified. The average height, average $\mathrm{DBH}$, and basal area were calculated for each plot. The relative contribution (\%) in living and dead basal area of each species was also calculated.

Subsequently, the basal areas of all the trunks of the plot were added, considering the class (type and condition) and converted to $\mathrm{m}^{2} \cdot \mathrm{ha}^{-1}$.

\section{RESULTS}

The structural parameters of the forest, where the trenches were excavated, are consistent with those presented by Estrada et al. (2013), with trunk density ranging from 1900 to 2500 live trunks.ha ${ }^{-1}$, 




Figure 2 - Excavation of the five trench to remove the belowground root biomass. The excavation was conducted with scale support to measure the exact $1 \mathrm{~m}^{3}$ volume of sediment. a) First trench; b) second trench; c) third trench; d) fourth trench; e) fifth trench.

the living basal area ranging from 25.96 to 36.84 $\mathrm{m}^{2}$.ha ${ }^{-1}$, the average DBH ranging from 11.00 to $12.66 \mathrm{~cm}$, the average height ranging from $9.10 \pm$ 2.58 to $10.33 \pm 2.27 \mathrm{~m}$, and the contribution in basal area indicating co-dominance of $A$. schaueriana and $R$. mangle (Table II)

The carbon stock estimates for Guaratiba mangrove belowground biomass ranged from 85.86 to 141.46 tC.ha $^{-1}$, with an average of 104.41 \pm 20.73 tC.ha ${ }^{-1}$. From this total, an average of $84.13 \pm 21.34 \mathrm{tC}^{\mathrm{C}} \mathrm{ha}^{-1}$ corresponds to the carbon stock only in fine roots, with diameters smaller than $5 \mathrm{~mm}$. The pneumatophores compartment presented a smaller carbon stock, averaging 0.13 \pm 0.13 tC.ha ${ }^{-1}$, which corresponds to less than $1 \%$ of all the carbon stock. Fine roots contribute up to $70 \%$ of the total belowground biomass; however, other authors have found smaller relationships of approximately $13 \%$ to $47 \%$ (Castañeda-Moya et al. 2011) and between 46 and 60\% (Komiyama et al. 1987). In this study the contribution of fine roots was superior, with approximately $80.1 \pm 6.4 \%$. In all strata, fine roots with diameters smaller than 5 $\mathrm{mm}$ accounted for over $60 \%$ of the belowground biomass carbon stock, and in the lower strata (deeper than $50 \mathrm{~cm}$ ) this contribution reached more than $90 \%$. 
TABLE II

Forest structure parameters of the plots measured around the trenches.

\begin{tabular}{|c|c|c|c|c|c|c|c|}
\hline \multirow{2}{*}{ Trench } & \multirow{2}{*}{ Density $^{1}$} & \multirow{2}{*}{$\mathbf{D B H}^{2}$} & \multirow{2}{*}{ Mean Height $( \pm \mathrm{SD})^{3}$} & \multirow{2}{*}{$\mathbf{B A}^{4}$} & \multicolumn{3}{|c|}{ Relative Dominance $^{5}(\%)$} \\
\hline & & & & & Species & Live & Dead \\
\hline \multirow{3}{*}{$\mathrm{T} 1$} & \multirow{3}{*}{2,500} & \multirow{3}{*}{11.42} & \multirow{3}{*}{$9.10 \pm 2.58$} & \multirow{3}{*}{29.91} & A. schaueriana & 48.5 & 14.3 \\
\hline & & & & & L. racemosa & 0.0 & 0.0 \\
\hline & & & & & R. mangle & 37.2 & 0.0 \\
\hline \multirow{3}{*}{$\mathrm{T} 2$} & \multirow{3}{*}{2,200} & \multirow{3}{*}{12.66} & \multirow{3}{*}{$9.70 \pm 1.98$} & \multirow{3}{*}{28.35} & A. schaueriana & 40.2 & 1.3 \\
\hline & & & & & L. racemosa & 0.0 & 0.0 \\
\hline & & & & & R. mangle & 57.5 & 1.1 \\
\hline \multirow{3}{*}{$\mathrm{T} 3$} & \multirow{3}{*}{2,200} & \multirow{3}{*}{12.60} & \multirow{3}{*}{$10.13 \pm 2.20$} & \multirow{3}{*}{29.38} & A. schaueriana & 47.0 & 1.1 \\
\hline & & & & & L. racemosa & 4.5 & 5.5 \\
\hline & & & & & R. mangle & 41.9 & 0.0 \\
\hline \multirow{3}{*}{$\mathrm{T} 4$} & \multirow{3}{*}{1,900} & \multirow{3}{*}{14.66} & \multirow{3}{*}{$10.33 \pm 2.27$} & \multirow{3}{*}{36.84} & A. schaueriana & 40.7 & 12.9 \\
\hline & & & & & L. racemosa & 0.0 & 0.0 \\
\hline & & & & & R. mangle & 46.4 & 0.0 \\
\hline \multirow{3}{*}{ T5 } & \multirow{3}{*}{2,200} & \multirow{3}{*}{11.00} & \multirow{3}{*}{$7.60 \pm 2.32$} & \multirow{3}{*}{25.96} & A. schaueriana & 30.4 & 19.5 \\
\hline & & & & & L. racemosa & 0.0 & 0.0 \\
\hline & & & & & R. mangle & 50.1 & 0.0 \\
\hline
\end{tabular}

Footnote: ${ }^{1}$ (live trunks.ha $\left.{ }^{-1}\right) ;{ }^{2}$ mean diameter at breast height $(\mathrm{cm}) ;{ }^{3}$ mean forest height $(\mathrm{m}) ;{ }^{4}$ basal area $\left(\mathrm{m}^{2}\right.$.ha $\left.{ }^{-1}\right) ;{ }^{5}$ based on living basal area.

Most of the carbon stock is concentrated in the more superficial sediment layers, up to $0.4 \mathrm{~m}$ deep, and corresponds to more than $50 \%$ of the belowground biomass carbon stock. However, the highest average of all strata is observed between 0.3 and $0.4 \mathrm{~m}$, with $16.23 \pm 3.14$ tC.ha $^{-1}$, which corresponds to $15.56 \%$ of the belowground biomass stock (Figure 3). The ratio between belowground root biomass stock and aboveground biomass stock (root:shoot) for the forests studied in Guaratiba is 1.14 based on estimates generated by Estrada et al. (2015) for the aboveground biomass carbon stock. This corresponds to a contribution of $53 \%$ of the carbon stock in plant biomass.

\section{DISCUSSION}

Belowground root biomass carbon stock in the world ranged from 0.5 tC.ha ${ }^{-1}$ to 263 tC.ha ${ }^{-1}$. The average carbon stock in fringe forest of Guaratiba mangroves was greater than about $80 \%$ of the values found in the literature.

Table SIII (Supplementary Material) depicts belowground biomass carbon stock values for different regions worldwide. For studies in which carbon stock values were not displayed, these were calculated using a more conservative approach, with a rate of $40.8 \%$ of carbon in the dry biomass. The stock estimated for Guaratiba was higher than that reported in most studies. However, other authors also found belowground biomass carbon stock values higher than those estimated for Guaratiba. There are several factors that can regulate the belowground biomass in mangrove forests, and consequently, the carbon stock associated with it. These factors include the position of the sampling area in relation to the water body, i.e., the flood tide frequency that the forest is subjected to, and the position in relation to the continent, i.e., if the forest is located in a more sheltered estuarine environment 


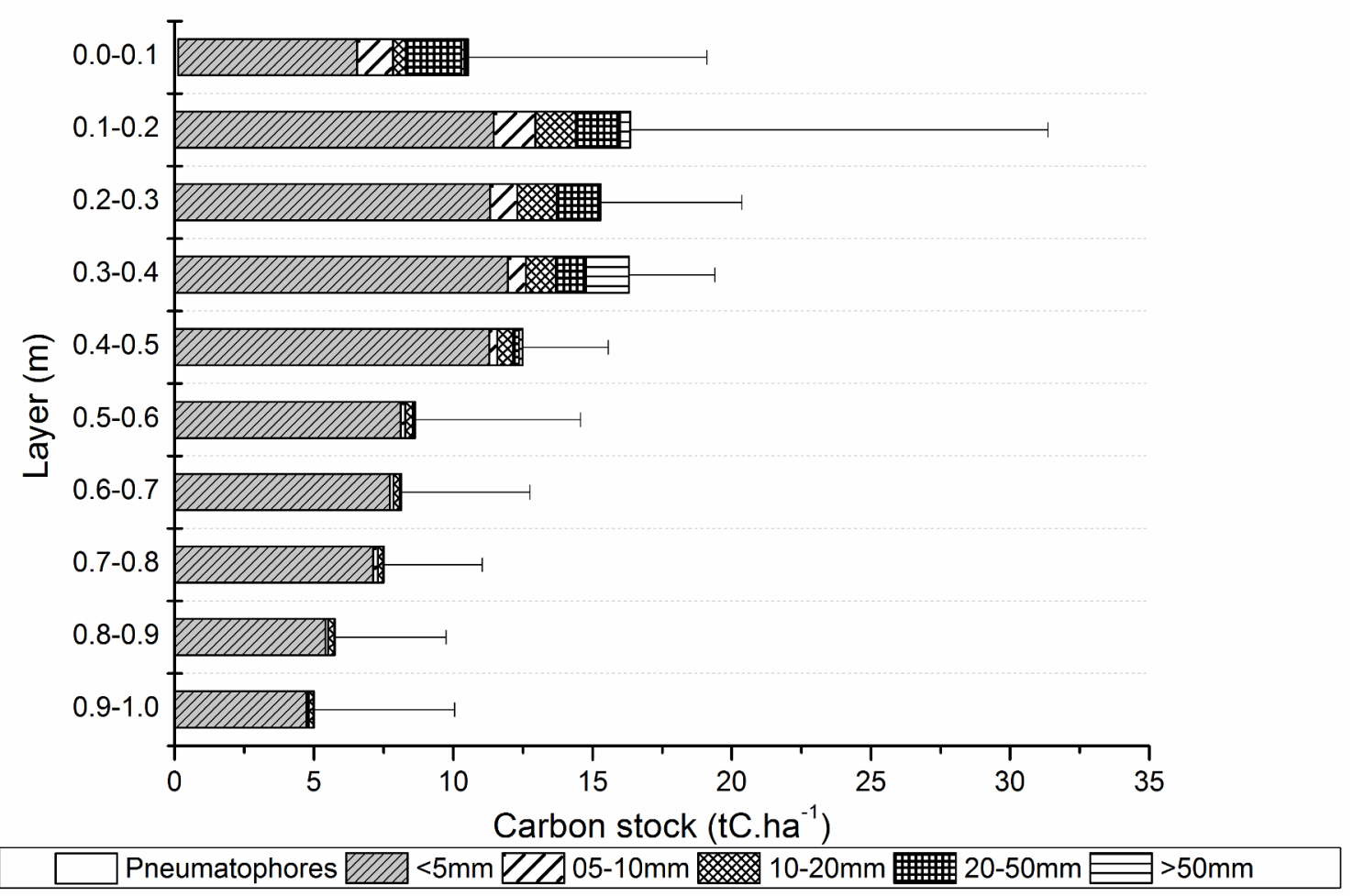

Figure 3 - Average carbon stock in root biomass by diameter classes in each deep.

or in an open area with a higher marine influence (Sherman et al. 2003, Donato et al 2011).

On the basis of the extensive review of belowground roots and aboveground biomass values of various forest land types in the world, Cairns et al. (1997) demonstrated that the root:shoot ratio ranges from 0.05 to 0.70 , with an average of 0.26 , with most studies reporting values between 0.20 and 0.30 . The root:shoot ratio for mangrove forests, therefore, tends to be higher than that for terrestrial forests, which can be explained by the need for a greater support for aboveground biomass in unstable substrate (Komiyama et al. 2008) and by the possible increase in cambial activity induced by ethylene production in immersion conditions (Yamamoto et al. 1995). Further studies in other ecosystems in Brazil, show that BGB in mangrove systems may be higher than in other. For example, Ribeiro et al. (2011) shows much lower values for Brazilian Savanna (Cerrado) than this study, even the mangroves occupying a much smaller area than Cerrado, wich occupies about $20 \%$ of Brazilian territory (MMA 2007). This distinctive feature of mangroves explains the importance of the belowground biomass as a carbon reservoir in that ecosystem, when compared with other forest systems. This shows that the carbon stock rates, in mangrove forest biomass, are considered high in relation to several others ecosystems (Cairns et al. 1997).

Thus the conservation of these forests allows the maintenance of carbon stock in the forest biomass. However, recent human activities have contributed to the degradation of these ecosystems (Ellison and Farnsworth 1996). In addition to these threats, mangroves are also threatened by possible climate changes (Soares et al. 2011). Processes of deforestation and degradation of these forests will allow the release of the carbon stock in the biomass as well as that stored in the sediment. 
This means high amounts of carbon released into the atmosphere through decomposition and bioavailability processes. The conservation of forest ecosystems of mangroves, as well as other ecosystems, allows a consequent maintenance of the carbon stock in the plant biomass (Harris et al. 2012, Zarin 2012).

The root:shoot ratio in carbon stock ranges from 0.21 to 1.55 (Komiyama et al. 2008). The values found here are within this range, but the contribution of belowground biomass for carbon stock in Guaratiba is greater than $90 \%$ of the values found in literature. However, most recently Zhila et al. (2014) found a lower contribution of carbon stock of belowground biomass with $1.3 \%$ equivalent to 0.01 root:shoot ratio.

Salinity can reduce the root biomass of non halophytes plants (Bernstein and Kafkafi 2002). However this is inversely in halophytes,for these plants, increased salinity induces the growth of roots and the reduction of salinity inhibits roots' growth (Bernstein and Kafkafi 2002). The root:shoot ratio can also be influenced by porewater salinity, where there may be a reduction of the aboveground biomass in relation to belowground biomass (Bernstein and Kafkafi 2002). This is to compensate for the soil conditions and reduce the need for nutrients and water by reducing the aerial part and increasing the biomass of roots to increasing the uptake of water and nutrients (Bernstein and Kafkafi 2002).

The highest concentration of carbon stock in the first layers of sediment was also found by Khan et al. (2007) other mangrove forests in the IndoPacific region. Donato et al. (2012) also reported a similar behavior for other mangroves where the stock tends to markedly decrease after the first 40 $\mathrm{cm}$ depth. The belowground biomass can be divided into compartments according to the diameter of the root (Komiyama et al. 1987), and consequently its carbon stock too. In a mangrove forests in southern Thailand over $50 \%$ of total root biomass was allocated in the fine roots $(<2 \mathrm{~mm}$ diameter $)$, the ratio ranged from $46.4 \%$ to $66.4 \%$, which shows a high root biomass of fine roots (Komiyama et al. 1987). Zhila et al. (2014) found a contribution of $27 \%$ and $37 \%$ of fine roots in carbon stock of the total forest biomass.

The fine roots in mangroves are concentrated in lateral branches that arise from perennial roots. The fine roots with diameters smaller than 2 $\mathrm{mm}$ are the primary source of water and nutrient uptake by plants and play an important role in the ecosystem, since without them the nutrients could not be absorbed and many inorganic and organic compounds have their cycles incomplete or damaged (Chalermchatwilai et al. 2011).

\section{CONCLUSIONS}

This study presented the first carbon stock estimates for the belowground biomass in southwestern Atlantic mangrove forests. The values found for Guaratiba, ranged from 85.86 to $141.46 \mathrm{tC}^{\mathrm{h}} \mathrm{ha}^{-1}$, with an average of $104.41 \pm 20.73$ tC.ha ${ }^{-1}$ (southeastern Brazil) are within the range reported in the literature, being compatible with the highest estimates presented for other regions. The trench sampling method, although very laborious, is considered, in the literature (Komiyama et al. 1987), more reliable and efficient because with this method there is practically no loss of material due to limitations of sampling in addition to the more representative volume of sampled material.

Although the aboveground biomass presents relevant participation in the mangrove forest carbon stock, the belowground biomass contribution has proven to be increasingly important as new studies are conducted showing that the ratio of aboveground and belowground biomass can be less than 1:1. That is, the belowground biomass can contribute more than $50 \%$ of the total biomass of mangrove forests. For Guaratiba the root:shoot ratio is 1.14 in the forests studied. 
This first carbon stock estimate of the belowground biomass of Brazilian mangrove forests begins to fill a huge gap of knowledge regarding this country $>$ s contribution to the mitigation of global warming, particularly considering that Brazil has the second largest area coverage of mangroves in the world. More efforts should be made to ensure that new estimates arise and allow not only the reduction of the uncertainty of the national inventory of carbon emissions but also the understanding of the carbon stock variability in this compartment in local, regional, and latitudinal scales.

\section{ACKNOWLEDGMENTS}

We thank to Empresa Brasileira de Pesquisa Agropecuária (EMBRAPA) - Agroindústria de Alimentos for field support and Fundação Carlos Chagas Filho de Amparo à Pesquisa do Estado do Rio de Janeiro (FAPERJ) for funding the study.

\section{REFERENCES}

ABOHASSAN RAA, OKIA CA, AGEA JG, KIMONDO JM AND MCDONALD MM. 2012. Perennial Biomass Production in Arid Mangrove Systems on the Red Sea Coast of Saudi Arab. Environ Res J 6(1): 22-31.

ALONGI D. 2014. Carbon Cycling and Storage in Mangrove Forests. Annu Rev Mar Sci 6: 195-219.

ALONGI D AND MUKHOPADHYAY SK. 2015. Contribution of mangroves to coastal carbon cycling in low latitude seas. Agr Forest Meteorol 213: 266-272.

BERNSTEIN N AND KAFKAFI U. 2002. Root Growth Under Salinity Stress. In: Plant Roots: The Hidden Half. Waisel Y, Eshel A and Kafkafi U (Eds). Marcel Dekker, p. 787-805.

BOUILLON S, FRANKIGNOULLE M, DEHAIRS F, VELIMIROV B, EILER A, ABRIL G, ETCHEBER H AND BORGES AV. 2003. Inorganic and organic carbon biogeochemistry in the Gautami Godavari estuary (Andhra Pradesh, India) during pre-monsoon: The local impact of extensive mangrove forests. Global Biogeochem Cy 17(4). Online. DOI: http://dx.doi.org/10.1029/2002GB002026.

BOUILLON S ET AL. 2008. Mangrove production and carbon sinks: A revision of global budget estimates. Global Biogeochem Cy 22(2). Online. DOI: http://dx.doi. org/10.1029/2007GB003052.
BRIGGS SV. 1977. Estimates of biomass in a temperate mangrove community. Aust J Ecol 2: 369-373.

BROWN S, LUGO AE AND IVERSON LR. 1992. Processes and lands for sequestering carbon in the tropical forest landscape. Water Air Soil Pollut 64: 139-155.

CAIRNS MA, BROWN S, HELMER EH AND BAUMGARDNER GA. 1997. Root biomass allocation in the world's upland forests. Oecologia 111: 1-11.

CASTAÑEDA-MOYA E, TWILLEY RR, RIVERAMONROY VH, MARX BD, CENAMO MC, PAVAN MN, BARROS AC AND CARVALHO F. 2010. Guia sobre projetos de REDD+ na américa latina. Manaus, Brasil, $96 \mathrm{p}$.

CHALERMCHATWILAI B, POUNGPARN S AND PATANAPONPAIBOON P. 2011. Distribution of fineroot necromass in a secondary mangrove forest in Trat province, Eastern Thailand. Science Asia 37: 1-5.

DONATO DC, KAUFFMAN JB, MACKENZIE RA, AINSWORTH A AND PFLEEGER AZ. 2012. Wholeisland carbon stocks in the tropical Pacific: Implications for mangrove conservation and upland restoration. J Environ Manage 97: 89-96.

DONATO DC, KAUFFMAN JB, MURDIYARSO D, KURNIANTO S, STIDHAM M AND KANNINEN M. 2011. Mangroves among the most carbon-rich forests in the tropics. Nature Geosci 4: 293-297.

ELLISON AM AND FARNSWORTH EJ. 1996. Anthropogenic Disturbance of Caribbean Mangrove Ecosystems: Past Impacts, Present Trends, and Future Predictions. Biotropica 28(4a): 549-565.

ESTRADA GCD, SOARES MLG, CHAVES FO AND CAVALCANTI VF. 2013. Analysis of the structural variability of mangrove forest through the physiographic types approach. Aquat Bot 111: 135-143.

ESTRADA GCD, SOARES MLG, FERNANDEZ V AND ALMEIDA PMM. 2015. The economic evaluation of carbon storage and sequestration as ecosystem services of mangroves: a case study from southeastern Brazil. Int J Biodivers Sci Ecosyst Serv Manage 11(1): 29-35.

GIRI C, OCHIENG E, TIESZEN LL, ZHU Z, SINGH A, LOVELAND T, MASEK J AND DUKE N. 2011. Status and distribution of mangrove forests of the world using earth observation satellite data. Global Ecol Biogeogr 20(1): 154-159.

GOLLEY F, ODUM H AND WILSON R. 1962. The structure and metabolism of a Puerto Rican red mangrove forest in May. Ecology 43: 9-19.

GOLLEY FB, MCGINNIS JT, CLEMENTS RG, CHILD GI AND DUEVER MJ. 1975. Mineral Cycling in a Tropical Moist Forest Ecosystem. Georgia Univ. Press, Athens, 248 p.

GUO Z, FANG J, PAN Y AND BIRDSEY R. 2010. Inventorybased estimates of forest biomass carbon stocks in China: 
A comparison of three methods. Forest Ecol Manag 259: 1225-1231.

HARRIS NS, BROW S, HAGEN SC, SAATCHI SS, SALAS W, HASEN MC, POTAPOV PV AND LOTSCH A. 2012. Baseline map of Carbon Emission from Deforestation in Tropical Regions. Science 336(6088): 1573-1576.

IPCC. 2014. Climate Change 2014: Synthesis Report. Contribution of Working Groups I, II and III to the Fifth Assessment Report of the Intergovernmental Panel on Climate Change [Core Writing Team, Pachauri RK and Meyer LA (Eds)]. IPCC, Geneva, Switzerland, 151 p.

KAUFFMAN JB, HEIDER C, COLE TG, DWIRE KA AND DONATO DC. 2011. Ecosystem Carbon Stocks of Micronesian Mangrove Forests. Wetlands 31: 343-352.

KHAN MNI, SUWA R AND HAGIHARA A. 2007. Carbon and nitrogen pools in a mangrove stand of Kandeliaobovata (S., L.) Yong: vertical distribution in the soil-vegetation system. Wetl Ecol Manag 15: 141-153.

KHAN MNI, SUWA R AND HAGIHARA A. 2009. Biomass and aboveground net primary production in a subtropical mangrove stand of Kandelia obovata (S., L.) Yong at Manko Wetland, Okinawa, Japan. Wetl Ecol Manag 17(6): 585-599.

KOMIYAMA A, HAVANOND S, SRISAWATT W, MOCHIDA Y, FUJIMOTO K, OHNISHI T, ISHIHARA S AND MIYAGI T. 2000. Top/root biomass ratio of a secondary mangrove (Ceriopstagal forest). Forest Ecol Manag 139: 127-134.

KOMIYAMA A, MORIYA H, PRAWIROATMODJO S, TOMA T AND OGINO K. 1988. Forest primary productivity. In: Ogino K and Chihara M (Eds), Biological System of Mangrove. Ehime University, p. 97-117.

KOMIYAMA A, OGINO K, AKSORNKOAE S AND SABHASRI S. 1987. Root biomass of a mangrove forest in southern Thailand. 1. Estimation by the trench method and the zonal structure of root biomass. J Trop Ecol 3: 97-108.

KOMIYAMA A, ONG JE AND POUNGPARN S. 2008. Allometry, biomass, and productivity of mangrove forests: A review. Aquat Bot 89: 128-137.

KUSMANA C. 1997. An Estimation above and below-ground tree biomass of a mangrove forests in East Kalimantan, Indonesia. J Biol Resour Manag 2(1): 20-26.

MACKEY AP. 1993. Biomass of the mangrove Avicennia marina (Forsk.) Vierh near Brisbane, south-eastern Queensland. Aust J Mar Fresh Res 44(5): 721-725.

MAGRIS RA AND BARRETO R. 2010. Mapping and assessment of protection of mangrove habitats in Brazil. Panam J Aquat Sci 5(4): 546-556.

MATSUI N. 1998. Estimated stocks of organic carbon in mangrove roots and sediments in Hinchinbrook Channel, Australia. Mangroves Salt Marshes 2: 199-204.
MMA - MINISTÉRIO DO MEIO AMBIENTE. 2007. Áreas Prioritárias para Conservação, Uso Sustentável e Repartição de Benefícios da Biodiversidade Brasileira: Atualização - Portaria MMA n 9 , de 23 de janeiro de 2007. Ministério do Meio Ambiente, Secretaria de Biodiversidade e Florestas. - Brasília: MMA, 301 p.

NASCIMENTO JR WR, SOUZA-FILHO PWM, PROISY C, LUCAS RM AND NOAA - NATIONAL OCEANIC E ATMOSPHERIC ADMINISTRATION. 2013. Trends in atmospheric carbon dioxide. Acessed http://www.esrl. noaa.gov/gmd/ccgg/trends/.

RAY R ET AL. 2011. Carbon sequestration and annual increase of carbon stock in a mangrove forest. Atmos Environ 45(28): 5016-5024.

RIBEIRO SC, FEHRMANN L, SOARES CPB, JACOVINE LAG, KLEINN C AND GASPAR RO. 2011. Above- and belowground biomass in a Brazilian Cerrado. Forest Ecol Manag 262(3): 491-499.

RODRIGUES DP, HAMACHER C, ESTRADA GCD AND SOARES MLG. 2014. Variability of carbon content in mangrove species: Effect of species, compartments and tidal frequency. Aquat Bot 120: 346-351.

SAATCHI SS ET AL. 2011. Benchmark map of forest carbon stocks in tropical regions across three continents, P Natl Acad Sci USA 108( 24): 9899-9904.

SCHAEFFER-NOVELLI Y, CINTRÓN-MORELO G, ADAIME RR AND CAMARGO M. 1990. Variability of mangrove ecosystems along the Brazilian Coast Estuaries 13: 204-218.

SCHAEFFER-NOVELLI Y, CINTRÓN-MOLERO G, SOARES MLG AND DE-ROSA T. 2000. Brazilian mangroves. Aquat Ecosys Health and Manag 3: 561-570.

SHERMAN ER, FAHEY JT AND MARTINEZ P. 2003. Spatial Patterns of Biomass and Aboveground Net Primary Productivity in a Mangrove Ecosystem in the Dominican Republic. Ecosystems 6: 384-398.

SIIKAMAKI J, SANCHIRICO JN AND JARDINE SL. 2012. Global economic potential for reducing carbon dioxide emissions from mangrove loss. P Natl Acad Sci USA 109(36): 14369-14374. DOI: www.pnas.org/cgi/ doi/10.1073/pnas.1200519109.

SOARES MLG, ALMEIDA PMM, CAVALCANTI VF, ESTRADA GCD AND SANTOS DMC. 2011. Vulnerabilidade dos Manguezais da Região Metropolitana do Rio de Janeiro Face às Mudanças Climáticas. In: Megacidades, Vulnerabilidades e Mudanças Climáticas: Região Metropolitana do Rio de Janeiro - Instituto Pereira Passos, p. 259-289.

SOTO-PINTO L, ANZUETO M, MENDOZA J, FERRER GJ AND JONG B. 2010. Carbon sequestration through agroforestry in indigenous communities of Chiapas, Mexico. Agroforest Syst 78: 39-51. 
TAMAI S, NAKASUGA T, TABUCHI R AND OGINO K. 1986. Standing biomass of mangrove forests in southern Thailand. J Jpn Forest Soc 68: 384-388.

TAMOOH F, HUXHAN M, KARACHI M, MENCUCCINI M, KAIRO JG AND KIRUI B. 2008. Below-ground root yield and distribution in natural and replanted mangrove forests at Gazi bay, Kenya. Forest Ecol Manag 256: 12901297.

TOMILSON PB. 1986. The Botany of Mangrove. Nova York (NY): Cambridge University Press, p. 419.

TWILLEY RR, CHEN RH AND HAGRIS T. 1992. Carbon sinks in mangroves and their implications to carbon budget of tropical coast ecosystems. Water Air Soil Pollut 64: 256288.

VIEIRA SA ET AL. 2008. Estimation of biomass and carbon stocks: the case of the Atlantic Forest. Biota Neotrop 8(2). Online. DOI: http://dx.doi.org/10.1590/S167606032008000200001 .
YAMAMOTO F, SAKATA T AND TERAZAWA K. 1995. Physiological, morphological and anatomical responses of Fraxinus mandshurica seedlings to flooding. Tree Physiol 15: 713-719.

ZARIN DJ. 2012. Carbon of Tropical Deforestation. Science 336: 1518-1519.

ZHILA H, MAHMOOD H AND ROZAINAH MZ. 2014. Biodiversity and biomass of a natural and degraded mangrove forest of Peninsular Malaysia. Environ Earth Sci 71: 4629-4635.

\section{SUPPLEMENTARY MATERIAL}

TABLE SIII - World mangroves carbon stock on belowground biomass for mangroves. (*carbon stock values estimated by converting the original biomass data with $40.8 \%$ of carbon in biomass rate proposed by Khan et al. 2007). 